WHY HAS LABOR NOT DEMANDED GUARANTEED EMPLOYMENT?

\author{
Jon D. Wisman \\ Michael Cauvel \\ Working Paper 2017-09 \\ http://www.american.edu/cas/economics/research/upload/2017-09.pdf
}

JEL No.: E24, J38, H10, N30

AMERICAN UNIVERSITY

4400 Massachusetts Ave., N.W.,

Washington, D.C. 20016-8029

\begin{abstract}
Unemployment has almost always been traumatic for its victims. In earlier times, it threatened extreme privation, if not starvation. Still today, it dramatically decreases its victims' standard of living, human capital, social standing, and self-respect. It is associated with poorer health, family dissolution, and suicide. Unemployment also entails considerable costs to society such as lost output, increased crime, decayed neighborhoods, and when extreme, political unrest. Why, then, is it tolerated? Why, especially, have workers and their advocates not demanded that employment be guaranteed to all? This article explores why what has always been foremost to workers' interests - security of employment - has only rarely resulted in a demand for guaranteed employment. The primary reason has been the overpoweringly seductive ideology serving the interests of the owners of the means of production. Capitalist ideology has blamed the unemployed for their fate, creating hostility to the very idea of guaranteed employment.
\end{abstract}


Working Paper, July 2017

\title{
WHY HAS LABOR NOT DEMANDED GUARANTEED EMPLOYMENT?
}

\author{
Jon D. Wisman and Michael Cauvel ${ }^{1}$
}

"A man willing to work, and unable to find work, is perhaps the saddest sight that fortune's inequality exhibits under this sun” (Thomas Carlyle 1840, Ch. 4)

"Work is about a search for daily meaning as well as daily bread, for recognition as well as cash” (Studs Terkel 1997).

\begin{abstract}
Unemployment has almost always been traumatic for its victims. In earlier times, it threatened extreme privation, if not starvation. Still today, it dramatically decreases its victims' standard of living, human capital, social standing, and self-respect. It is associated with poorer health, family dissolution, and suicide. Unemployment also entails considerable costs to society such as lost output, increased crime, decayed neighborhoods, and when extreme, political unrest. Why, then, is it tolerated? Why, especially, have workers and their advocates not demanded that employment be guaranteed to all? This article explores why what has always been foremost to workers' interests - security of employment - has only rarely resulted in a demand for guaranteed employment. The primary reason has been the overpoweringly seductive ideology serving the interests of the owners of the means of production. Capitalist ideology has blamed the unemployed for their fate, creating hostility to the very idea of guaranteed employment.
\end{abstract}

JEL Classification Codes: E24, J38, H10, N30

Keywords: right to employment, employer of last resort, unemployment, worker struggles, ideology

Unemployment has always been harrowing for its victims. Prior to modern times, it meant extreme privation, and even starvation. Despite today's safety nets, it continues to dramatically decrease the unemployed's standard of living, along with their skills, their social standing, and their self-respect. It is associated with poorer health, family dissolution, suicide, and stands as the major cause of poverty. Unemployment also entails such costs to society as lost output, welfare costs, increased crime, and decayed neighborhoods. Why, then, is it tolerated? Why in particular have workers themselves not demanded that employment be guaranteed to all? Arguably, guaranteed employment at a living wage would constitute the most progressive gain possible for workers within a society of private property and markets.

Prior to workers' acquisition of the franchise in the nineteenth century, a demand for guaranteed employment would have met with little success. However, having won the franchise and become the overwhelming majority of the electorate, they could use their political power to

\footnotetext{
${ }^{1}$ The authors are Professor of Economics and Ph.D. candidate in economics at American University, Washington, D.C.
} 
override business interests and force government to provide jobs for all. Why have they not done so? Why has guaranteed employment not always been at the top of worker movements' political agendas?

Marx characterized capitalism as a social system in which workers have no ownership, control, or ready access to the means of production. Consequently, to survive they must locate owners willing to provide them with jobs. The fact that not all workers are able to do so is serviceable to the owners in holding down wages and enforcing worker discipline. Guaranteed employment at a living wage would radically curb the power of the owners of the means of production and provide workers with security of livelihoods. It would also force private employers to offer better-paid, more interesting, and safer work to draw employees from the pool of those hired within a guaranteed work program. Given these highly promising conditions for workers, it might be expected that guaranteed employment would be among their primary demands.

Yet history reveals that a widespread and sustainable demand for guaranteed employment has never occurred. In the very few incidents in which workers have supported, demanded, and even revolted to obtain guaranteed employment programs, their petitions were short-lived. Hence the question: If guaranteeing employment is as good an idea as its proponents claim, ${ }^{2}$ why has it not always been more central to worker movements and the platforms embraced by political parties representing their interest and vying for their votes?

This article explores this question. It finds that the principal force standing against the very idea has been the persuasive success of dominant ideology, which, Marx made clear, in every society has always been that which represents the interests of property-owning elites. ${ }^{3}$ As he put it, "The class which has the means of material production at its disposal, has control at the same time over the means of mental production, so that the ideas of those who lack the means of mental production are subject to it” $(1845,172) .{ }^{4}$ Within capitalism, this ideology has depicted capitalism as natural, delivering abundance and freedom that dynamically improves the welfare of everyone, enables anyone by dint of hard work to rise to the top, and therefore the best of all economic systems, within which involuntary unemployment is nonexistent, the unemployed being themselves to blame for their unwillingness to seek and accept available employment.

Indeed, identifying the unwillingness of the unemployed to diligently pursue work has always been the greatest barrier to any claim that employment should be guaranteed to all. Attention is generally deflected from the extreme inequality in the ownership of the means of production, or when noted, is not deemed inappropriate because the owners earned it, and anyone through hard work could do so as well. Given the pervasiveness and seductiveness of this ideology, it has been internalized by most workers themselves. When workers have entertained

\footnotetext{
${ }^{2}$ See: (Attali and Champain 2005); (Darity 2010); (Forstater 1998; 2006); (Harvey 1989); (Kaboub 2012); (Mitchell and Wray 2005); (Palley 2001); (Vickrey 1992); (Wisman 2010; 2013a); (Wisman and Pacitti 2014; 2017); (Wisman and Reksten 2013); (Wray 1998a; 1999); 2007; 2006).

${ }^{3}$ Although Marx's theory of ideology is often dismissed as merely exhibiting his political biases, Schumpeter, from the other end of the political spectrum, thought otherwise: "Marx was the economist who discovered ideology for us and who understood its nature. Fifty years before Freud, this was a performance of the first order" $(1954,35)$.

${ }^{4}$ Accordingly, the bourgeoisie had been able to take political power from the aristocracy because it came to control capital, the principal evolving means of production, along with an ideology legitimating this ownership. Nothing parallel to this occurs for the proletariat. They struggle for political power without command over the means of production and thus command over ideology. They have only their greater numbers.
} 
views hostile to capitalism, they generally sought either its replacement or reforms other than guaranteed employment. But over capitalism's history, most workers did not seek the overthrow of capitalism. Instead, they internalized its ideology and most frequently focused their struggle more locally on their workplaces. ${ }^{5}$

This article explores the manner in which ideology delegitimated the potential for guaranteed employment to the point that the very idea has only rarely arisen, even among unions, worker movements, or progressives who advocate for the interests of workers.

The article unfolds as follows. The next section notes workers’ principal demands. The third section addresses the lack of support for guaranteed employment among intellectual reformers. The fourth section explores the dynamics of ideology. The fifth section traces the rise of capitalism and the problem of unemployment. The sixth section surveys the nineteenth century expansion of worker political power. The seventh section examines ways in which capitalist ideology was reinforced. The eigth section examines the relative delegitimation of laissez-faire ideology during the Great Depression. The ninth section addresses the resurgence of laissez-faire ideology since the 1970s. The article ends with a few final reflections on the importance of ideology and why labor has generally fared so poorly in its struggles.

\section{Workers' Demands}

Workers have been incited to rebelliousness by high unemployment, high food prices, and food shortages (see e.g. Lieberman 1986, 12; Davis 1989, 210). But only very rarely have they demanded guaranteed employment. Instead, they and political parties claiming to represent their interests struggled principally for reforms such as limited work hours, minimum wages, restricted child labor, safer working conditions, education for their children, and the franchise (Phillips 1989, Magraw 1989, Geary 1989, Davis 1989). At times, they have also focused on issues such as piecework, the pace of work, and the cruelty of factory foremen (Magraw 1989; Phillips 1989). Major unions in Europe have also at times advocated programs such as early retirement incentives, reducing the work week, raising the minimum years of schooling, and banning married women from the work place to reduce the workforce and thus unemployment (Garraty 1978, 191). And in some instances, a few worker movements clamored for a revolutionary replacement of capitalism with socialism or communism.

But beyond a brief French demand for guaranteed employment in the late 1840s, there are only a few other examples, all without sustainability or substantial consequence. One is that of U.S. workers in the 1930s (discussed below); another the Deutscher Gewerkschaftsbund (DGB) in 1949 in Germany; and a third, the Martin Luther King-led March on Washington for Jobs and Freedom in 1963. The "Principles of Economic Policy" formulated by the DGB demanded "full employment for all those willing to work" (Lieberman 1986, 153-4), while the organizers of the March on Washington in 1963, sponsored by American labor organizations such as the AFL-CIO, ${ }^{6}$ included among their demands "a massive federal program to train and place all unemployed workers.” But most labor organizations, both in Europe and the U.S., stopped short of calling for an employment guarantee and did little more than pay lip service to the idea of public works (Garraty 1978, 191).

\footnotetext{
${ }^{5}$ Note that even in contemporary times, workers and the political parties that claim to represent their interests generally accept that at some point short of full employment, expansionary fiscal or monetary policy must be subdued lest excessive inflationary pressure arise - the infamous "natural rate of unemployment" (NAIRU). To term this rate "natural" is nothing less than ideological obfuscation.

${ }^{6}$ However, a disclaimer notes that not all supporting organizations necessarily endorse all the stated demands.
} 


\section{Little Help from Intellectual Social Reformers}

Although dominant ideology has never been supportive of guaranteed employment, a very few social thinkers did advocate a right to work. The idea surfaced in the late eighteenth century as a component of what were proclaimed as natural rights, especially among members of the French Enlightenment. In January 1776, Anne Robert Jacques Turgot presented six edicts before the Counsel in which is found: "God, in giving humans needs made work necessary and thereby made the right to work a property of all humans, and this right is the first, the most sacred, and the most inalienable of all rights” (authors’ translation) (Turgot March 16, 2016). Similarly, Jean Baptiste Joseph Fourier, claimed a natural right to work (un droit au travail) stemming from the right to life (le droit à l'existence), which was possessed by all in a state of nature (Fourier 2007, 190-96). He held that these rights would be fully delivered in his system of phalanxes, or communal forms of organization.

Robert Owen's "Villages of Cooperation” similarly began as a means of providing relief for the unemployed, although his vision blossomed into a plan for the complete reorganization of society (Harrison 1969, 12-13). But apart from Owen, few social thinkers outside of France championed the idea of the right to work. Most English socialists gave the idea practically no notice, and mainstream thinkers none that was positive. ${ }^{7}$ Similarly, in Germany, although a few thinkers took up the question of a right to work, their views received little attention, either among intellectuals or the working class (Spengler 1968).

In face of the harsh conditions for workers during the industrial revolution, it is not surprising that many workers were attracted to the idea that capitalism needed to be replaced by a more humane system. Revolutionary intellectuals promising a more humane alternative often found ready followers, drawing attention away from reformist ideas such as guaranteed employment and toward revolutionary struggle. For example, not all workers enthusiastically supported the guaranteed employment promised by the National Workshops in Paris in the late 1840s because "to early exponents of the communist ideal it seemed insufficiently radical" (Rosanvallon 2013, 114). The Industrial Workers of the World (IWW) proclaimed, "Instead of the conservative motto, 'A fair day's wages for a fair day's work,' we must inscribe on our banner the revolutionary watchword, 'Abolition of the wage system.'” (cited in Brooks 1969, 87). Others, such as Marx and his followers, saw unemployment as an ineradicable feature of capitalism, only to be eliminated by its socialist replacement.

Yet even those who advocated and militated for the overthrow of capitalism generally supported reforms as highly desirable until the final goal could be realized. They did not, however, include guaranteed employment as one of their intermediate goals.

\section{The Dynamics of Ideology}

During the first 97-98 percent of human existence as foragers and then early agriculturalists, little inequality or exploitation existed. However, the rise of civilization and the state about 5,500 years ago, following upon an elite's command of superior metal weaponry (Boix 2015), permitted them to subjugate all others. The elite's strong comparative advantage in violence and its ownership and control of land forced all others to work on their land either as slaves, serfs, indentured peasants or in indentured servitude, permitting the expropriation of their

\footnotetext{
${ }^{7}$ Even John Stuart Mill, whose sympathies were generally with the workers and the less fortunate wrote: "When the pay is not given for the sake of the work, but the work found for the sake of the pay, inefficiency is a matter of certainty: to extract real work from day-labourers without the power of dismissal, is only practicable by the power of the lash” (Mill 1909, 363). Mill also believed that guaranteed employment would lead to excessive population growth.
} 
surplus value. Enabling this exploitation to be more peaceful and thus efficient, ideology evolved that legitimated the prevailing social order. Throughout civilized history, the elite's superior influence over the generation and character of ideology has played a usually decisive role in the maintenance of their ability to control labor and appropriate most of society's surplus. Beyond violence, ideology has always been their most powerful political weapon.

Ideology is thus deception, although not usually conscious deception. It is a form of mystification that serves specific interests. It promotes a mistaken view of aspects of reality, most importantly, social aspects and social relations, such as to permit elites to exploit all others. In this manner, it has always been a powerful instrument for creating and maintaining inequality (Wisman and Smith 2011).

Ideology is an aspect of legitimation. Legitimation refers to a set of beliefs concerning the nature of reality. It concerns how people mentally experience and understand their world. As such, it is neither positive nor negative. Humans evolved such that they must give meaning to their world (Berger and Luckmann 1967). Ideology, by contrast, refers to the way in which reality is mystified so as to serve special interests. It presents a false view of social relations, enabling the exploitation of some by others.

Humans have produced three broad, highly interrelated categories of tools to control their world. A highly simplified way of putting this is that technology promises more efficient control of the physical world, social institutions promise more efficient coordination of social processes, and legitimation permits control of the mental world. Ideology is a subdomain of legitimation. These three broad categories overlap and are highly interrelated in their functioning. Technology influences social processes and mental acts. Institutions can control physical processes and mental acts. And legitimation affects and controls all that humans do. ${ }^{8}$

At times, war, or economic, demographic, ecological, or natural catastrophes brought on crises severe enough to threaten the elite's ideology and thus their fitness to rule. However, since the rise of the state, their superior command over ideology always permitted them to eventually reclaim legitimacy and control over labor and its surplus.

Elite control can be maintained by either physical or ideological force, as has been recognized by social thinkers since Machiavelli. Physical force has often been necessary for initially establishing and solidifying a hierarchical social structure. However, brute force is relatively inefficient in that it generates strong resentment, the constant threat of insurrection, and is costly in terms of policing. A far more efficient and effective long-run strategy is for elites to generate an ideological system that convinces not only themselves but all beneath them of the moral and functional appropriateness of the existing social order. Those below are led to believe that their lesser status in terms of income, wealth, and privilege is as it must be.

Ideological control is generally expressed through the manipulation of social discourse. As Jim Sidanius and Shana Levin put it,

“...almost all perspectives on legitimizing ideologies suggest that their power is derived from their consensuality....legitimizing ideologies are believed to be effective in regulating group-based inequality because they are often endorsed by dominants and subordinates alike. All other things being equal, the greater the degree to which both dominants and subordinates agree on the veracity of hierarchy-enhancing legitimizing myths, the less physical violence will be necessary to keep the system of stratification intact” (2001, 316).

\footnotetext{
${ }^{8}$ Capturing the dynamic interrelationships among technology, social institutions, and social consciousness was central to Marx’s conception of an adequate social science (Wisman 2013b).
} 
For subjugation of labor to be efficiently sustainable, workers must be led to believe that their inferior status in terms of income, wealth, and privilege is as it must be. And strikingly, Elizabeth Haines and John Jost find that "people may be more willing to accept relatively illegitimate accounts than is commonly assumed...[and the authors] found that people misremembered the explanations that were given to them as more legitimate than they actually were” (2000, 232). And, as Thorstein Veblen astutely observed, "The fact that the usages, actions, and views of the well-to-do leisure class acquire the character of a prescriptive canon of conduct for the rest of society gives added weight and reach to the conservative influence of that class. It makes it incumbent upon all reputable people to follow their lead” (Veblen 1934, 200).

With the exception of periods of extreme crises, elite control has always been adequately legitimated such that most folks found it acceptable, even when it meant their lives were filled with extreme hardship and misery. This was especially true if all other sufferers remained quiescent. As Tolstoy famously noted, there are "no conditions of life to which a man cannot get accustomed, especially if he sees them accepted by everyone around him” (2017).

During the greater part of history, an aristocracy controlled access to land and the dominant ideology legitimated their privileged position. Under capitalism, the owners of capital control access to the means of production and an ideology rose to dominance that legitimates the institutions and practices of capitalism.

The owners of capital have understandable reason to oppose guaranteed employment. It would eliminate a "reserve army of the unemployed" that holds down wages and disciplines workers. They would have to offer good pay and working conditions to attract workers who could always fall back upon the guaranteed employment program. Although guaranteed employment might stimulate productivity, economic growth, and aggregate demand, its fiscal cost would, at least initially and in part, disproportionately fall upon the elite. Consequently, within capitalism, views and attitudes would evolve that would be unfriendly even to the concept of guaranteed employment.

Throughout its history, capitalism's dominant ideology has always maintained that involuntary unemployment is either nonexistent or impossible to eliminate, and consistently placed the blame on the slothfulness of the unemployed. This placement of responsibility on the unemployed themselves has, excepting periods of massive unemployment, seemed plausible. Surely if they diligently searched for employment, they would be able to find it. And during periods of massive unemployment, blame could be shifted to scapegoats, such as foreigners, immigrants, unions, regulations, or excessive taxes on the rich that dampen incentives to save and invest, rather than requiring that government fully guarantee employment. These views have typically been internalized by workers themselves, leading them to blame themselves, or scapegoats, but not "the system."

Unemployment is psychologically debilitating for its victims, rendering them vulnerable to self-blame for their condition. Professor of psychiatry James Gilligan claims that the inability to find a job is the foremost driver of shame and worthlessness (2011). In The Road to Wigan Pier, George Orwell observed: "When I first saw unemployed men at close quarters, the thing that horrified and amazed me was to find that many of them were ashamed of being unemployed.... The middle classes were still talking about 'lazy idle loafers on the dole' and saying that 'these men could all find work if they wanted to', and naturally these opinions percolated to the working class themselves” (1937, Ch. 5). Peter Temin wrote of the debilitating passivity that accompanies unemployment as follows: 
"Unemployed men in the European Great Depression were exceedingly idle; an increase of apathy reduced all forms of recreational activity. Men passed their time doing essentially nothing; when asked, they could not even recall what they had done during the day. They sat around the house, went for walks, or played cards and chess. Most men went to bed early; there simply was no reason to stay awake. They contributed less to the running of the household than before, sometimes not even turning up on time for meals” $(2008,681){ }^{9}$

Understandably, such behavior would appear to others as slothful, evidence of an unwillingness to seek out employment as responsible individuals should.

In addition, as Melvyn Dubofsky puts it, workers have always faced the twin challenges of "social inertia combined with the inability of most workers and their leaders to conceive of an alternative to the values of marketplace capitalism” (1986, 223).

\section{The Rise of Capitalism and the Problem of Unemployment}

Unemployment first became a major social problem with the evolution of capitalism. Prior to this, workers in agriculture were generally fused with the land as slaves, serfs, indebted peasants, or in indentured servitude. Those in crafts generally owned the tools with which they worked. Although an unemployed class of paupers had always existed, it was usually too marginal to pose a threat to public order. However, during the early evolution of capitalism, unemployment became more widespread due to social dynamics which Marx termed primitive accumulation to characterize the separation of producers from any ownership or control of the means of production. Workers were pushed and pulled from their traditional rights to be on the land that they cultivated. They were pushed by the enclosure movement ${ }^{10}$ and pulled by better conditions in towns. ${ }^{11}$ The superior productivity of rising industrial production increasingly bankrupted independent craftsmen. Workers were being proletarianized, turned into free laborfreed from feudal fetters, but no longer retaining any ownership, control, or ready right of access to the tools and resources with which to work. To survive, they had to locate employers willing to give them wage work. ${ }^{12}$ Those who failed in doing so would be unemployed. While this pool of unemployed workers was functional for capitalists in holding down wage levels and imposing worker discipline, it posed a political threat to the state when they became rebellious. This threat became acute as the urbanization that accompanied capitalism concentrated the unemployed in

\footnotetext{
${ }^{9}$ Amartya Sen writes that unemployment “....may generate a loss of cognitive abilities as a result of the unemployed person's loss of confidence and sense of control” $(1997,161)$. Additionally, “The discouragement that is induced by unemployment can lead to a weakening of motivation and make the long-term unemployed more resigned and passive...There is...considerable evidence suggesting that the typical effect, especially of long-term unemployment, is one of motivational decline and resignation. This can yield a hardening of future poverty and further unemployment..." (1997, 162-63). Sen’s analysis is supported by William Darity’s research: "We observed that since spells of unemployment and even underemployment produce learned helplessness, low self-esteem, and depression, those spells can lead to reduced intensity and persistence of search, reduced cognitive efficiency, and reduced motivation to acquire skills that might improve prospects for re-employment” $(1999,495)$.

${ }^{10}$ Landlords forced serfs and peasants off the land so as to more profitably use it for pasturage and commercial farming as markets for agricultural output expanded.

${ }^{11}$ A part of the pull is captured in the medieval German saying, "Stadtluft macht frei” (Town air makes you free).

12 Thus, as Marx noted, they were free in a dual sense: free from feudal fetters, but also free of any ownership or control of the means of production. Consequently, "The wage worker..."is compelled to sell himself of his own free will" (Marx 1967, 3:766).
} 
urban centers where they collectively and often spontaneously revolted, especially during general downturns when unemployment soared.

While the state recognized unemployment as a problem, it was viewed as one of social order, rather than of justice or human welfare. Nevertheless, the political necessity of full employment served as a common end to most mercantilist policies. ${ }^{13}$

Because unemployment was viewed as harmful to the state and the unemployed were blamed for their unemployment, they were generally treated as criminals. The dominant ideology depicted them as slothful and unwilling to seek work. In England, for instance, the resulting harshness toward them is vividly captured by the Statute of 1536, subjecting them on first discovered offense to a public whipping in the nude, on second offense to whipping plus loss of part of their right ear, and on third offense, should the unemployed still not be willing to "put himself to labor like as a true man oweth to do [to] pains and execution of death" (Byrne 2010, 42). ${ }^{14}$

The new religions of the Reformation were especially unsympathetic to the plight of the unemployed. Their adherents had been "nurtured in a tradition which made discipline of character by industry and self-denial the center of its ethical scheme.” Luther "denounced the demands of the beggars as blackmail” (Tawney 1926, 221, 220). R.H. Tawney writes of the prevailing view:

“That the greatest of evils is idleness, that the 'idle, irregular and wicken courses,' that the truest charity is not to enervate them by relief, but so to reform their characters that relief may be unnecessary - such doctrines turned severity from a sin into a duty, and froze the impulse of natural pity with the assurance that, if indulged, it would perpetuate the suffering which it sought to allay" (1926, 221).

So widespread was the ideology of the workers' slothfulness that even the enlightened David Hume recommended imposing a tax on the poor to goad them into working more (1905, 247). Although the overwhelming explanation for unemployment was the slothfulness of the unemployed, Malthus added luck, capturing the widespread lack of sympathy for their fate:

"A man who is born into a world already possessed, if he cannot get subsistence from his parents, on whom he has a just demand, and if the society does not want his labour, has no claim of right to the smallest portion of food, and, in fact has no business to be where he is. At nature's mighty feast there is no vacant cover for him” (1986, WS 3, p. 697-698 (1803 edition).

Many of the unemployed could only survive by turning to crime, which when apprehended often resulted in their deportation to colonies, a method by which the state effectively reduced unemployment and the threat it posed to social order. ${ }^{15}$ Another response was

\footnotetext{
${ }^{13}$ So threatening was high unemployment that legislation was considered in the English Parliament to provide those in distress with employment. It is noteworthy, however, that the goal was social peace rather than worker "rights" or wellbeing. Also, support for such legislation came not from the working class, but from above, from those who blamed the unemployed for their unemployment, but feared social disorder. (Tawney 1926, 219).

${ }^{14}$ A pamphleteer wrote in 1646 that "The general rule of all England is to whip and punish the wandring beggars." (Cited in Tawney 1926, 219). In 1649, an Act was passed to provide a company with the power to apprehend vagrants and to offer them the choice of a whipping or work. A generation later, Fletcher of Saltoun proposed that they be "sent to the galleys" (Tawney 1926, 220).

${ }^{15}$ Prisons continue to serve this function today. For instance, the prison population in the U.S. currently constitutes 1.5 percent of the work force and functions to reduce unemployment and the social threat to, and legitimacy of, the government.
} 
forcing them into dehumanizing workhouses, which were utilized less with the intention of aiding the unemployed than as means of punishment (Garraty 1978, 48). Eric Hobsbawn wrote that "the jail-like workhouse forcibly separated husbands, wives and children in order to punish the poor for their destitution, and discourage them from the dangerous temptation of procreating further paupers” (1968, 69-70). With such an alternative, the insecurity and destitution that accompanied unemployment may have been preferable, as evidenced by the fact that "poor people were known to sell the shirts off their backs to avoid the workhouse” (Garraty 1978, 84). Yet despite their unpopularity, they existed for about 350 years, appearing in the U.S. during the nineteenth and first 40 years of the twentieth century as poor houses, usually on farmland. These workhouses served to mitigate the blemish and threat that the unemployed posed to governments' legitimacy. ${ }^{16}$

Following the decline of mercantilism, most economic thinkers (e.g. Quesnay, Smith, and Say) saw unemployment as a problem originating in mercantilist privileges and rigidities, believing that if these monopoly and regulatory forces were dismantled and markets left free, then workers would readily find work. The implication is that all unemployment in a free market system is voluntary. If the unemployed were to seek employment in earnest, wages would be bid down until it would be profitable for employers to hire all available workers. The fact that this does not happen is testimony to the unwillingness of some workers to actively seek employment or accept the available jobs. Thus, they are to blame.

\section{Industrialization and the Rise of Worker Political Power}

Rapid industrialization and urbanization during the nineteenth century created the possibility, as Marx observed and further anticipated, that the working class could organize and threaten violence against the elites' state for redress. To reduce and hopefully eliminate this threat, the elite-controlled state, to an extent unexpected by Marx, began bribing the working class with various benefits and with the franchise. Although both strategies for calming working class revolutionary fervor resulted in a lowering of the amount of surplus that the ruling elite could expropriate, the alternative of violence and revolution promised to be far worse. They realized, as Edward Muller and Mitchell Seligman observe, that "the presence of meaningful nonviolent possibilities of influencing the political process will inhibit the ability of revolutionary-minded dissidents to mobilize large followings” $(1987,444)$. Moreover, improvements for workers gave credence to the elites' claim that capitalism was in everyone's best interest.

Prior to gaining the franchise, workers lacked the political power necessary to gain guaranteed employment. However, with the right to vote came the possibility that workers could use the political system to force the government to provide employment for all. Thus, it is no coincidence that the first employment guarantee was granted concurrently with an extension of the franchise in France. Following massive unemployment generated by the economic crisis of 1946 and the subsequent Revolution of 1848, the provisional government sought to appease workers by granting them suffrage and relieving unemployment, proclaiming on February 25, 1848: "The French Republic undertakes to guarantee the existence of the workmen by work. It undertakes to guarantee work for every citizen," setting up National Workshops to fulfill this

\footnotetext{
${ }^{16}$ Tawney writes that "The writers who advanced schemes for reformed workhouses, which should be places at once of punishment and of training were innumerable. All were agreed that, on moral no less than on economic grounds, it was vital that wages should be reduced [being in agreement with Arthur Young's statement that] 'everyone but an idiot knows that the lower classes must be kept poor, or they will never be industrious’” (Tawney 1926, 224).
} 
guarantee (McKay 1933, 3-9). In the few months after their creation, the Workshops employed 120,000 and 50,000 had to be turned away. Workers were provided with regular wages, free medical care, and food allowances for themselves and their families (McKay 1933, xi-xii, 25-6).

The National Workshops were shut down after about a year, not due to their inefficiency, but because they had never been seen as anything but a temporary measure to appease workers until elections had passed and political stability was reestablished (McKay 1933, 77). Workers responded with a revolt (the June Days Revolution) which was put down with brutal force within a matter of days (Traugott 1985, 31).

The mid-nineteenth century demand for guaranteed employment by French workers did not persist, nor did workers in other countries follow suit upon winning the right to vote. Although elites lost formal monopoly control over the political process, they retained dominant influence over ideology. They generally succeeded in convincing workers that the best interests of those who owned and controlled the means of production were in fact the best interests of the workers as well. Laissez-faire economic and political thought continued to offer support and refinement to this ideology. ${ }^{17}$ And to buttress its power, two ideological weapons were added: Social Darwinism and Nationalism.

The doctrine of Social Darwinism rose to prominence in the second half of the nineteenth century-during the same period when workers were gaining the franchise in many countries. Social Darwinism depicted society as naturally competitive, and if this competitiveness could be unfettered much as laissez-faire doctrine insisted, social progress would ensue. A critical component of this competition is that the fittest survive and the unfit do not. Accordingly, the unemployed are not only to blame for their failure to find jobs, but they are unfit, a view that could be internalized in workers' minds, prompting them to blame themselves. Those with jobs could look upon the unemployed as unfit losers. Like laissez-faire economic thought, Social Darwinism suggests that creating employment for the jobless would be counterproductive, in this case because it would impede social progress. This theory served as a powerful force countering demands for social reforms. As Richard Hofstadler notes, although the ideas behind Social Darwinism were not new, they served to provide validation for laissez-faire ideology, giving "the force of a [new] natural law to the idea of competitive struggle” (1992, 6).

The second addition to the elite's ideological arsenal was heightened nationalism. It arose most powerfully in periods of high unemployment toward the end of the nineteenth century when blaming the victims would be least persuasive. Nationalism deflected attention from social dysfunction as the cause of unemployment to the unfair competition of foreigners. This surge of nationalism accorded with the doubt cast by Thorstein Veblen on Marx's expectation that workers would overthrow capitalism. Veblen claimed that workers might instead "sink their force in the broad sands of Patriotism" (1961, 442).

In France, for instance, attention was deflected from workers' demands for a fairer share to national protectionism that took on a "violently xenophobic and anti-Semitic" character. As Pierre Rosanvallon puts it, "The transition from revolutionary radicalism to ultranationalism was one of the period's most striking examples of ideological and political reclassification” (2013, 144). This ideology emphasized protecting "national labor" against immigrant workers and to give it substance, it was proposed that employers using foreign workers be subject to a special tax. Street demonstrations grew in the 1890's with attacks on Italian immigrants in the north of France. Although such actions were opposed by socialist parties and unions, they were powerless

\footnotetext{
${ }^{17}$ For instance, neoclassical economics' marginalism permitted its theory to be modelled using calculus, giving it the patina of a science like physics, thereby enhancing its legitimating force.
} 
to stop them (Rosanvallon 2013, 147). Workers in the U.S. also joined in racism against an influx of Chinese workers. A referendum on Chinese immigration passed with overwhelming support in California in 1879. Even members of the Workingmen's Party and Knights of Labor participated in physical attacks on Asian workers (Rosanvallon 2013, 163).

The effectiveness of turning workers against each other in terms of race and ethnicity has borne fruit for the elite. Transnational research has found a strong correlation between social homogeneity and redistributive policies. The more heterogeneous the society, the less the expenditures on social programs (Alesina and Glaeser 2006). Further, “....across the United States, the states with the smallest percentage of African Americans in their population offer the most generous social benefits” (Rosanvallon 2013, 163). Gerald Friedman writes of how “...the legacy of slavery and large-scale immigration hindered working-class unity by dividing American workers along racial, ethnic, and cultural lines” $(1988,23) .^{18}$

Protectionism can also play an ideological role by generating a kind of solidarity not unlike that of patriotism. So too did imperialism. Cecil Rhodes famously offered, "He who would avoid civil war must be an imperialist” (cited in Rosanvallon 2013, 142), echoing Hegel's observation that "peoples involved in civil strife ...acquire peace at home through making war abroad” (1958, 295). As Rosanvallon puts it, "Colonialism...counterbalanced and camouflaged domestic inequalities by depicting the nation as a community in confrontation with the rest of the world” $(2013,143)$. As a result of the solidarity this ideology inspired, workers have commonly supported policies that attempt to "export the problem" of unemployment; e.g., the tactics favored by European unions in the 1930s to combat high unemployment included "the repatriation of foreign workers ... high protective tariffs and mounting campaigns urging consumers not to buy foreign-made goods” (Garraty 1978, 191). Today, this ideology has been at work in Brexit, the election of Donald Trump, and the considerable popularity of France's Marine Le Pen.

\section{Further Supplementing Classic Capitalist Ideology}

Blaming the unemployed themselves for their joblessness is made more effective by the fact that unemployment generally affects only a small portion of the total labor force. As noted earlier, the shame and sense of worthlessness and resulting lethargy that typically accompanies unemployment makes the victims readily blamed for their condition, all the more so when unemployment-generated lethargy impedes an energetic search for employment.

Although during severe downturns, political pressures increase the likelihood of government intervention in aid of the unemployed (Folsom 1991, 28), ideological opposition to government programs may be expected to increase as well (Mian, Sufi, and Trebbi 2014). Businesses face falling profits, and guaranteed employment or merely employment-generating public works could put upward pressure on wages and entail greater budget deficits, both being claimed to impair recovery (Garraty 1978, 159; 191), as witnessed in the call for fiscal austerity in the wake of the crisis of 2008. Further, workers have weakened bargaining power in periods of high unemployment, resulting in fewer strikes (Magraw 1989, 66-7; Geary 1989, 109).

Occasionally, even unions have accepted the argument that public works programs should only be adopted insofar as they do not compromise governments’ ability to balance budgets (Garraty 1978, 191)

\footnotetext{
${ }^{18}$ Friedman continues, "While dividing the working class, large-scale immigration may have contributed to the remarkable unity of the elite in the United States. Most businessmen, judges, and national politicians were whites from Protestant and English-speaking backgrounds. Their common heritage united them against union members and strikers, many of whom were immigrants, blacks, or Catholics” $(1988,23)$.
} 
Workers more often blame their firms and their bosses, rather than the state, for unemployment. It is the bad bosses and greedy firm owners, along with sold-out politicians, who are the targets of workers' wrath. This tendency to not blame society's institutions, but individuals instead, may be a legacy of early human evolution. For the first 97 to 98 percent of our species' existence, humans lived as foragers without readily identifiable social institutions. If something was amiss, it was individuals or groups of individuals who were to blame, not abstract institutions. Accordingly, humans were selected to determine character, which evolved into our acute sense of justice and our sensitivity to unfair treatment. ${ }^{19}$ The consequence is that when social institutions fail such as with a financial crisis or depression, people are strongly inclined to blame it on the greedy and corrupt actors (bankers, corporate leaders, politicians) rather than the institutional structure - the politically determined rules of the game -- that sets the incentives for the behavior that is found at fault. Consequently, attention is focused on finding people morally deficient, thereby deflecting attention from the need to modify social institutions. Note that blame for the financial crisis of 2008 was largely placed with Wall Street bankers, who were depicted as greedy and corrupt, as opposed to inadequately regulated financial institutions that had evolved to become dysfunctional for the economy.

Unions have generally viewed their task as protecting their own workers, as opposed to the entire working class. For instance, in the U.S., the rise of "business unionism" led union leaders to be more conservative and act to serve the special interests of their unions rather than serve as "a social movement in the interest of all workers" (Le Blanc 1999, 75). ${ }^{20}$

Historically, to the extent that workers did pressure governments to alleviate the problem of unemployment, they more readily turned to their local, rather than national governments. These local governments, with limited resources, have been incapable of creating more comprehensive solutions to unemployment, such as guaranteed employment. Folsom provides numerous examples of times when unemployed workers organized to demand public works programs and relief from city governments (1991). Early in the history of the United States, for example, these demands were more common than petitions to the federal government to ease the problem of unemployment. Until the Great Depression, unemployment was generally viewed as a local rather than a federal problem (Wasem 2013, 15).

Finally, throughout the history of capitalism, it has been argued that the burden of alleviating unemployment should be left to private charities. For instance, during the early years of the Great Depression in the United States, this argument was widely expressed, and often supported by the media (Folsom 1991, 238).

\section{The Great Depression and the Partial Delegitimation of Laissez-faire Ideology}

\footnotetext{
${ }^{19}$ Brain scans confirm that humans are hardwired for a sense of fairness or justice, and that this explains, for instance, why there is intense pleasure, imagined or actually taken, in getting revenge (Roach 2004). Note the rapid and spontaneous reaction of "road rage" to perceived or imagined disrespect on roadways. Experimental results from the ultimatum game have consistently demonstrated the importance of a sense of fairness (Gintis et al. 2005, 11-13).

${ }^{20}$ Challenging Marx’s prediction of an increasingly militant and revolutionary working class, Thorstein Veblen contended that "The growth of the capitalistic system presently brought on trade-unionism...an organized attempt on the part of the workmen to deal with the question of capitalistic production and distribution by business methods, to settle the problems of working-class employment and livelihood by a system of non-political, businesslike bargains" (1961, 449). This has been truer in the U.S. than in Europe.
} 
The severity of the Great Depression delegitimated strict adherence to laissez-faire ideology that had dominated social thought since the early nineteenth century. Claiming that massive unemployment was due to the laziness of the unemployed and therefore voluntary was no longer as convincing, and in the U.S., the ideal of a right to work received considerable attention. This is especially remarkable for two reasons: the leader of a major capitalist society, Franklin Delano Roosevelt, advocated guaranteed employment, and laissez-faire ideology had been arguably stronger in the U.S. than in European nations.

During the 1930s in the U.S., three job-creation programs employed 1.4 to 4.4 million workers each month (Rose 2013, 155), all with widespread popular support. Paradoxically, this popularity impeded their expansion, as political opposition mobilized amidst fears that if they became too extensive and entrenched, the working classes would never permit them to end (Harvey 1989, 105). Nevertheless, rising support for the right to work led to the inclusion of guaranteed employment in an early draft of the Social Security Act of 1935, although it was excised from the final version.

In 1943, Roosevelt proposed a "New Bill of Rights" that would have entailed the "formal acceptance by the Federal Government of responsibility for insuring jobs at decent pay to all those able to work regardless of whether or not they can pass a means test" (Rose 2013, 170). In his 1944 State of the Union address, Roosevelt advocated an "economic bill of rights" that would include the "right to a useful and remunerative job" and the "right to earn enough to provide adequate food and clothing, and recreation” (cited in Rose 2013, 170). ${ }^{21}$

Despite the macroeconomic stimulation of the public job-creation programs, the Great Depression only came to an end with the beginning of World War II. ${ }^{22}$ The success of the government's ability to coordinate the war mobilization effort increased confidence that government actions could lead to permanent full employment (Wasem 2013, 11). This growing confidence, along with the increasing support for the right to work, set the stage for the Full Employment Act of 1946, the original draft specifying that "all Americans able to work and seeking work have the right to useful, remunerative, regular, and full-time employment" (cited in Rose 2013, 170), obliging the Federal government to guarantee employment. Despite widespread public support -- public opinion polls showed that over two-thirds of Americans believed the government should provide jobs for any person willing and able to work but unable to find a job (Bailey 1950, 9) -- this provision of the bill failed to pass either house of Congress (Wasem 2013, 143).

The United States was unique in having a head of state push for legislation guaranteeing employment. However, a number of other countries incorporated language concerning full employment and the right to work in their constitutions during the 1940s (Bailey 1950, 11). The Labour party in England "came into office in 1945 under the banner of eradicating the five giant evils of want, squalor, disease, ignorance, and unemployment” (Appleby 2011, 289). The right to work was also included in the United Nation's 1948 Universal Declaration of Human Rights (Article 23, Section 1).

\footnotetext{
${ }^{21}$ Populist governor Huey Long in his 1934 “Share Our Wealth Plan” also argued for guaranteed work through public works to ensure jobs for everyone.

${ }^{22}$ The war revealed once more the power of nationalism, as it "resolved the contradictions of American capitalism and substituted patriotic unity for class conflict” (Dubofsky 1986, 213). The Cold War that followed the war continued to serve this ideological function.
} 
Despite failure to secure an employment guarantee, worker welfare greatly improved between World War II and the mid-1970s. Inequality substantially decreased, education was significantly more democratized, universal health care was instituted in most of Europe, and worker rights greatly expanded. Though workers did not win the guarantee of employment, arguably they were pacified by higher incomes and the greater security that came with these social welfare policies, including unemployment insurance. Workers demanded "work or maintenance” and governments found the latter less threatening to capitalism (Acemoglu and Robinson 2000; Garraty 1978, 147-8).

Support for the view that the unemployed are to blame for their joblessness declined in the first three-quarters of the $20^{\text {th }}$ century, especially in the wake of the Great Depression (Garraty 1978).

\section{The Resurgence of Laissez-faire Ideology}

However, this trend did not last long, as laissez-faire ideology returned to prominence following stagflation in the 1970s, which delegitimated government intervention in the economy in the eyes of many. In the face of simultaneous high unemployment and high inflation, Keynesian aggregate demand management appeared impotent, if not mistaken. It was in this anti-government climate that the last attempt to strengthen the government's commitment to full employment was made in the U.S. The Employment and Balanced Growth Act of 1978, commonly known as Humphrey-Hawkins, was originally intended to increase the government's commitment to full employment (Wasem 2013). However, concern over inflation became the primary argument against the bill (Ginsburg 1983, 70), and it was altered to provide government with a dual mandate - to attain both full employment and price stability (Wasem 2013). Alarm over government debt was deployed to generate a commitment to a balanced budget in the final bill (Harvey 1989, 111), and the guaranteed employment provisions were weakened such that the bill would have no impact on the government's employment policies (Ginsburg 1983, 76). ${ }^{23}$

Since the 1970s, the threat of inflation has not only stood in the way of advocacy of guaranteed employment, it has delegitimized arguments for stimulative macroeconomic polices to lower unemployment in general. The dominant argument among economists and politicians is that any attempt to push unemployment below its "natural” rate leads to inflation, creating a kiss of death for the very notion of guaranteed employment. ${ }^{24}$

\footnotetext{
${ }^{23}$ It is noteworthy that Charles Schultze, Chair of the Council of Economic Advisors during democratic President Jimmy Carter's term, forcefully and successfully fought against retention of language that committed the government to full employment, evidence of increasingly broad acceptance of laissez-faire ideology and a declining commitment on the part of the Democratic Party to the interests of workers.

${ }^{24}$ Many advocates of government as an employer-of-last resort program (ELR) believe it would create an initial inflationary shock, especially if ELR wages were set above minimum wages. Also, its introduction would increase aggregate demand if the increase in government spending were not offset by cuts in other government spending or increases in taxes. However, Mitchell and Wray (2005) and Wray (1998b) argue that after its introduction, it would be anti-inflationary, or failing that, at least non-inflationary. But would not guaranteed employment embolden workers to demand higher wages? Wray counters this possibility by noting that

“...while workers have the alternative of ELR jobs, employers have the opportunity of hiring from the ELR pool. Thus if the wage demands of workers in the private sector exceed by too great a margin the employer's calculation of their productivity, the alternative is to obtain ELR workers at a mark-up over the ELR wage. This will help to offset any wage pressures caused by elimination of the fear of unemployment" $(2007,18)$.
} 
The resurgence of laissez-faire ideology has revived the view that the unemployed are inadequately motivated to seek work, justifying slashing welfare programs. Even Democratic President Bill Clinton embraced this view and shepherded through Congress the Personal Responsibility and Work Opportunity Reconciliation Act of 1996, which cut public assistance to force the unemployed to seek jobs. High unemployment in most of Europe is currently leading governments there to trim back assistance to the unemployed to force them to seek employment, on the presumption that they are not diligently doing so and are thus blameworthy.

The resurgence of this ideology has also generated wide support for the claim that government is incompetent and wasteful (Wisman 2013c), such that if workers were to be guaranteed employment, it would be in make-work projects of no social value and at considerable taxpayer expense.

In this climate, even political parties claiming to represent the interests of workers do not embrace a call for guaranteed employment. The accompanying change in public opinion is telling: Whereas about 75 percent of survey respondents in 1945 thought that the government should ensure employment for all, only about $40 \%$ expressed this view in recent iterations of the General Social Survey (Smith, Hout, and Marsden 2013). Although there is more support for this view outside of the United States (ISSP Research Group 2008a), there have not been any major efforts by labor interests or political parties to obtain guaranteed employment. ${ }^{25}$ Yet more striking is that so few progressive movements take up the issue. No socialist or other left-ofcenter political party in Europe or the U.S. has embraced and advanced a call for guaranteed employment. ${ }^{26}$

\section{Concluding Thoughts}

The question that set this article in motion is why, given the critical importance of employment security for workers, have they rarely included guaranteed employment among their demands. During early capitalism, their chances of gaining this right were nil. But once the urbanization that accompanied industrialization made it possible for them to organize and successfully fight for and win the franchise, they in principal could have rewritten the social script to better meet their needs. To a very limited degree they did just that. Their political muscle led to impressive improvements in their quality of life, including limits to the work day, restrictions on child labor, safer workplaces, state provided pensions, education for their children, better sanitation, and in Europe, socialized medicine. But why did they not go for more? Why did they not use their political power to flatten out in a more sustainable manner the huge disparities of income, wealth, and privilege that have always existed between the rich and

\footnotetext{
${ }^{25}$ Limited programs resembling guaranteed employment have been enacted in Argentina and rural India, but neither appears to be the result of worker demands. Argentina implemented an ELR program from 2002-2006, following social unrest amid a massive economic crisis (Kostzer 2008, 2-8; Wray 2007, 31). Yet the program stopped short of codifying a legal right to work, and much of the impetus for the ELR program came from the top, rather than from below. In the case of India, the 2005 National Rural Employment Guarantee Act does explicitly guarantee the right to work, albeit with important restrictions. The law seems to be the result of unique characteristics of the Indian labor market. For example, there is a substantial amount of underutilized labor in the agricultural sector, and unemployment rates are typically very low in India because workers must accept any job, even at wages below subsistence, due to the lack of social safety nets provided by the government, private charities, or any other source (Kamath 2010).

${ }^{26}$ In the 2017 French presidential elections, in an economic climate of persistent high unemployment, the Socialist candidate advocated a universal income scheme. Of the multiple candidates in this election, none, not even the Communist Party, advocated guaranteed employment.
} 
everyone else? And why did they not demand guaranteed employment and thereby gain freedom from the ever-present threat of joblessness?

The only convincing response is that elites with ownership of the means of production have successfully generated ideology that adequately legitimates prevailing inequality and an economy in which workers, without ownership, control, or ready access to the means of production, must locate owners or their agents willing to provide them with employment. ${ }^{27}$ The seldom expressed, almost silent ideology is that elites have a right to own and control the means of production, forcing all others to prostitute their labor time to survive. And the far-from-silent ideology that those who fail to find work are slothful and thus to blame for their condition has successfully worked since the early evolution of capitalism.

The extraordinary success of this ideology is that the very idea of guaranteed employment is alien to most people. A common response to its mention is "but that's communism, that's what the Soviet Union did!” Even progressive movements and socialist parties do not put it onto their platforms. ${ }^{28}$

Marx saw the differentia specifica of capitalism as the separation of workers from all ownership and control of the means of production and its concentrated ownership within a small elite class. Although guaranteed employment at a living wage would not eliminate this differentia specifica, it would dampen considerably its harshest consequences. As it did so, it would substantially change the social power between the owners of the means of production and workers. It would force employers to offer better-paid, more interesting, and safer work to attract employees from the pool of those within a guaranteed work program. It would lead to lessened inequality. It would create a floor of security and dignity beneath all workers.

The dominant ideology has been supple enough to generally allow the substantial gains that workers have made since they won the franchise, although it continually wars against them. The power of this ideology is such that a far more substantial reform, that of guaranteed employment, does not even make it into public discourse. Guaranteed employment does not exist because prevailing ideology keeps it off the agenda even of workers and those who politically represent their interests.

Marx's claim that "The class which has the means of material production at its disposal, has control at the same time over the means of mental production" is truer than he realized. ${ }^{29}$

\section{References}

\footnotetext{
${ }^{27}$ The inequality that has always most mattered is that part of total wealth which is the means of production, the tools and resources with which work is carried out. It is far more extreme than indicated by wealth inequality and far less often noted. In the U.S., for instance, in 2007, the wealthiest one percent of Americans owned 49.3 percent of stocks and mutual funds, the richest 10 percent, 89.4 percent, leaving the bottom 90 percent with only 10.6 percent (Wolff 2010: Table 9: 52). It is this ownership that subjugates non-owners.

${ }^{28}$ In the United State, this has just changed. On May 16, 2017, the Center for American Progress proposed a job guarantee at a living wage (Tanden et al. 2017).

${ }^{29}$ Indeed, it is not clear that the "class consciousness" that Marx predicted for the working class ever existed more than sporadically. C. Wright Mills claimed that for class consciousness to exist, "there must be 1) a rational awareness and identification with one's own class interests; 2) an awareness of and rejection of other class interests as illegitimate; and 3) an awareness of and a readiness to use collective political means to the collective political end of realizing one’s interests” (Mills 1936, 325).
} 
Acemoglu, Daron, and James A. Robinson. 2000. "Why Did the West Extend the Franchise? Democracy, Inequality, and Growth in Historical Perspective.” The Quarterly Journal of Economics 115 (4): 1167-99. doi:10.1162/003355300555042.

Alesina, Alberto, and Edward L. Glaeser. 2006. Fighting Poverty in the US and Europe. New York: Oxford University Press.

Appleby, Joyce. 2011. The Relentless Revolution: A History of Capitalism. Reprint edition. New York, NY: W. W. Norton \& Company.

Attali, Jacques, and Vincent Champain. 2005. Changer Le Paradigme Pour Supprimer Le Chômage. Paris: Paris: Foundation Jean-Jauares. http://www.metiseurope.eu/content/pdf/n9/6_attali.pdf.

Bailey, Stephen Kemp. 1950. Congress Makes a Law: The Story Behind the Employment Act of 1946. New York: Columbia University Press.

Berger, Peter L., and Thomas Luckmann. 1967. The Social Construction of Reality: A Treatise in the Sociology of Knowledge. New York: Anchor.

Boix, Carles. 2015. Political Order and Inequality: Their Foundations and Their Consequences for Human Welfare. New York: Cambridge University Press.

Brooks, John Graham. 1969. American Syndicalism: The I.W.W. New York: AMS Press.

Byrne, Edmund. 2010. Work, Inc.: A Philosophical Inquiry. Temple University Press.

Carlyle, Thomas. 1840. Chartism. London, J. Fraser. http://archive.org/details/chartism00carlgoog.

Cochran, Bert. 1978. Labor and Communism: The Conflict That Shaped American Unions. Princeton, N.J: Princeton University Press.

Darity, William. 2010. “A Direct Route to Full Employment.” Review of Black Political Economy 37: 179-81.

Darity, William, Jr. 1999. “Who Loses from Unemployment?” Journal of Economic Issues 33 (2): 491-96.

Davis, John A. 1989. "Socialism and the Working Classes in Italy before 1914.” In Dick Geary (Ed.), Labour and Socialist Movements in Europe before 1914, First Edition edition, 182-230. Oxford; New York: New York: Berg.

Deaton, Angus. 2013. The Great Escape: Health, Wealth, and the Origins of Inequality. Princeton, N.J: Princeton University Press.

Dubofsky, Melvyn. 1986. "Not So 'Turbulent Years': A New Look at the 1930s.” In Life and Labor: Dimensions of American Working-Class History, edited by Charles Stephenson and Robert Asher, 205-23. Albany: State University of New York Press.

Eriksson, Tor, and Jingkun Li. 2008. "Restructuring Meets Flexicurity: Housekeeping Work in Danish Hotels.” In Low-Wage Work in Denmark, edited by Niels Westergaard-Nielsen. New York: The Russell Sage Foundation.

Erixon, Lennart. 2010. “The Rehn-Meidner Model in Sweden: Its Rise, Challenges and Survival.” Journal of Economic Issues 44 (3): 677-715.

Folsom, Franklin. 1991. Impatient Armies of the Poor: The Story of Collective Action of the Unemployed, 1808-1942. 1st edition. Niwot, Colo: Univ Pr of Colorado.

Forstater, Mathew. 1998. "Flexible Full Employment: Structural Implications of Discretionary Public Sector Employment.” Journal of Economic Issues 32 (2): 557-63.

_. 2006. "Green Jobs: Public Service Employment and Environmental Sustainability.” Challenge 49 (4): 58-72. 
Fourier, Charles. 2007. “Selection from the Work of Fourier.” In . Whitefish, MT: Kessinger Publishing Company.

Friedman, Gerald. 1988. "Strike Success and Union Ideology: The United States and France, 1880-1914.” The Journal of Economic History 48 (1): 1-25.

Gaiha, Raghav. 1996. “The Employment Guarantee Scheme in India: Is It Mistargeted?” Asian Survey 36 (12): 1201-12. doi:10.2307/2645575.

Garraty, John A. 1978. Unemployment in History. 1st ed. New York: Harper \& Row.

Geary, Dick. 1989. "Socialism and the German Labour Movement before 1914.” In Dick Geary (Ed.), Labour and Socialist Movements in Europe before 1914, First Edition edition, 101-36. Oxford; New York : New York: Berg.

Gilligan, James. 2011. Why Some Politicians Are More Dangerous than Others. New York: Polity Books.

Ginsburg, Helen. 1983. Full Employment and Public Policy: The United States and Sweden. Lexington Books.

Gintis, Herbert, Samuel Bowles, Robert Boyd, and Ernst Fehr. 2005. "Moral Sentiments and Material Interests: Origins, Evidence, and Consequences.” In Moral Sentiments and Material Interests: The Foundations of Cooperation in Economic Life. Cambridge, Mass: MIT Press.

Goldberg, Arthur J. 1956. AFL-CIO Labor United. McGraw Hill Book Co.

Haines, Elizabeth L., and John T. Jost. 2000. "Placating the Powerless: Effects of Legitimate and Illegitimate Explanation on Affect, Memory, and Stereotyping." Social Justice Research 13 (3): 219-36. doi:10.1023/A:1026481205719.

Harrison, J.F.C. 1969. Quest for the New Moral World: Robert Owen and the Owenites in Britain and America. New York: Charles Scribner's Sons.

Harvey, Philip. 1989. Securing the Right to Employment. Princeton, NJ: Princeton University Press.

Hegel, Georg Wilhelm Friedrich, and T. M Knox. 1958. Hegel's Philosophy of Right. London: Oxford at the Clarendon Press.

Heilbroner, Robert L. 1999. The Worldly Philosophers: The Lives, Times And Ideas Of The Great Economic Thinkers, Seventh Edition. 7th Revised edition. New York: Touchstone.

Herman, Carl. 2016. “'Remaining Awake through a Great Revolution’: Dr. King’s Last Sermon to You Washington's Blog.” Accessed January 13.

http://www.washingtonsblog.com/2013/01/remaining-awake-through-a-great-revolutiondr-kings-last-sermon-to-you.html.

Hobsbawn, E. J. 1968. Industry and Empire: An Economic History of Britain since 1750. First American Edition, Stated edition. London: WEIDENFELD \& NICOLSON.

Hofstadter, Richard. 1992. Social Darwinism in American Thought. Reprint edition. Boston: Beacon Press.

Hume, David. 1905. Essays. London; New York: G. Routledge and Sons ; E.P. Dutton.

ISSP Research Group. 1992. "International Social Survey Programme: Role of Government II ISSP 1990.” ZA1950 Data file Version 1.0.0. Cologne: GESIS Data Archive. doi:10.4232/1.1950. . 2008a. "International Social Survey Programme: Role of Government I-IV - ISSP 19851990-1996-2006.” ZA4747 Data file Version 1.0.0. Cologne: GESIS Data Archive. doi:10.4232/1.4747. 
. 2008b. "International Social Survey Programme: Role of Government IV - ISSP 2006.” ZA4700 Data file Version 1.0.0. Cologne: GESIS Data Archive. doi:10.4232/1.4700.

Kaboub, Fadhel. 2007. "Employment Guarantee Programs: A Survey of Theories and Policy Experiences.” Working Paper 498. Levy Economics Institute Working Paper Collection. Levy Economics Institute. http://estes.levy.org/pubs/wp_498.pdf.

—. 2012. “The Low Cost of Full Employment in the United States.” In The Job Guarantee: Toward True Full Employment, edited by Mathew Forstater and Michael Murray. New York: Palgrave Macmillan.

Kamath, Rajalaxmi. 2010. "National Rural Employment Guarantee Act: An Effective Safety Net?” IIMB Management Review 22 (1-2): 42-55. doi:10.1016/j.iimb.2010.03.004.

Karson, Marc. 1958. American Labor Unions and Politics. Southern Illinois University Press.

Kostzer, Daniel. 2008. “Argentina--A Case Study on the Plan Jefes Y Jefas de Hogar Desocupados, or the Employment Road to Economic Recovery.” Levy Economics Institute, The, Economics Working Paper Archive, 2008. http://www.levyinstitute.org/pubs/wp_534.pdf.

Le Blanc, Paul. 1999. A Short History of the U.S. Working Class: From Colonial Times to the Twenty-First Century. Amherst, N.Y: Humanity Books.

Lieberman, Sima. 1986. Labor Movements and Labor Thought: Spain, France, Germany, and the United States. New York: Praeger.

Magraw, Roger. 1989. “Socialism, Syndicalism and French Labour.” In Dick Geary (Ed.), Labour and Socialist Movements in Europe before 1914, First Edition edition, 48-100. Oxford; New York : New York: Berg.

Malthus, Thomas Robert. 1986. The Works of Thomas Robert Malthus. London: Pickering. Marx, Karl. 1845. “The German Ideology.” In The Marx-Engels Reader, edited by Robert C. Tucker, 2nd ed., 146-202. New York: Norton \& Co. . 1967. Capital: A Critique of Political Economy. Vol. 3. 3 vols. New York: International Publishers Company, Incorporated.

McKay, Donald Cope. 1933. The National Workshops: A Study in the French Revolution of 1848. Harvard Historical Studies. Cambridge: Harvard University Press.

Mian, Atif, Amir Sufi, and Francesco Trebbi. 2014. "Resolving Debt Overhang: Political Constraints in the Aftermath of Financial Crises.” American Economic Journal: Macroeconomics 6 (2): 1-28.

Mill, John Stuart. 1909. Principles of Political Economy, 7th Ed. 7th ed. Clifton, NJ: Augustus M. Kelley.

Mills, C. Wright. 1936. White Collar. New York: Oxford University Press.

Mitchell, William, and L. Randall Wray. 2005. "In Defense of Employer of Last Resort: A Response to Malcolm Sawyer.” Journal of Economic Issues 39 (1): 235-43.

Muller, Edward N., and Mitchell A. Seligman. 1987. "Inequality and Insurgency.” The American Political Science Review 81 (2): 425-52.

Orwell, George. 1937. “The Road to Wigan Pier.” http://georgeorwell.org/The_Road_to_Wigan_Pier/index.html.

Palley, Thomas I. 2001. “Government as Employer of Last Resort: Can It Work?” Industrial Relations Research Association 53: 269-74.

Phillips, Gordon. 1989. “The British Labour Movement before 1914.” In Dick Geary (Ed.), Labour and Socialist Movements in Europe before 1914, First Edition edition, 11-47. Oxford; New York: New York: Berg. 
Roach, John. 2004. "Brain Study Shows Why Revenge Is Sweet.” National Geographic News. August 27.

http://news.nationalgeographic.com/news/2004/08/0827_040827_punishment.html.

Rosanvallon, Pierre. 2013. The Society of Equals. Cambridge, Mass: Harvard University Press.

Rose, Nancy E. 2013. "Bring Back the WPA: Lessons from the Job Creation Programs of the 1930s.” In Employment Guarantee Schemes: Job Creatin and Policy in Developing Countries and Emerging Markets, edited by Mathew Forstater and Michael J. Murray. New York: Palgrave Macmillan.

Saposs, David J. 1972. Social and Economic Studies of Post-War France, Volume IV: The Labor Movement in Post-War France. New York: Russell \& Russell.

Schumpeter, Joseph A. 1954. History of Economic Analysis. New York: Oxford University Press.

Sen, Amartya. 1997. “Inequality, Unemployment and Contemporary Europe.” International Labour Review 136 (2): 155-72.

Sidanius, Jim, and Shana Levin. 2001. “Legitimizing Ideologies: The Social Dominance Approach.” In The Psychology of Legitimacy: Emerging Perspectives on Ideology, Justice, and Intergroup Relations, edited by John T. Jost and Brenda Major, 307-31. Cambridge: Cambridge University Press.

Smith, Tom W., Michael Hout, and Peter V. Marsden. 2013. “General Social Survey, 1972-2012 [Cumulative File]: Version 1." http://www.icpsr.umich.edu/ICPSR/studies/34802/version/1.

Spengler, Joseph J. 1968. "Right To Work: A Backward Glance.” The Journal of Economic History 28 (02): 171-96. doi:10.1017/S0022050700069291.

T, Neera, en, Carmel Martin, Marc Jarsulic, Brendan Duke, Ben Olinsky, Melissa Boteach, John Halpin, Ruy Teixeira, and Rob Griffin. 2017. "Toward a Marshall Plan for America." Center for American Progress. May 16.

https://www.americanprogress.org/issues/economy/reports/2017/05/16/432499/towardmarshall-plan-america/.

Tanden, Neera, Carmel Martin, Marc Jarsulic, Brendan Duke, Ben Olinsky, Melissa Boteach, John Halpin, Ruy Teixeira, and Rob Griffin. 2017. "Toward a Marshall Plan for America.” Center for American Progress. May 16. https://www.americanprogress.org/issues/economy/reports/2017/05/16/432499/towardmarshall-plan-america/.

Tawney, R. H. 1926. Religion and the Rise of Capitalism. New York: Harcourt, Brace \& World.

Temin, Peter. 2008. "Real Business Cycle Views of the Great Depression and Recent Events: A Review of Timothy J. Kehoe and Edward C. Prescott's Great Depressions of the Twentieth Century.” Journal of Economic Literature 46 (3): 669-84.

Terkel, Studs. 1997. Working: People Talk About What They Do All Day and How They Feel About What They Do. New York: The New Press.

“The Universal Declaration of Human Rights.” 2014. Accessed June 22. http://www.un.org/en/documents/udhr/.

Thompson, E. P. 1963. E. P. Thompson, The Making of The English Working Class [New York: Vintage, 1963. New York: Vintage.

Tolstoy, Leon. 2017. “A Quote from Anna Karenina.” Goodreads. http://www.goodreads.com/quotes/74806-there-are-no-conditions-to-which-a-personcannot-grow. 
Traugott, Mark. 1985. Armies of the Poor: Determinants of Working-Class Participation in the Parisian Insurrection of June 1848. Princeton N.J.: Princeton University Press.

Turgot, Anne Robert Jacques. March 16, 20016. “Les Édits.” Imago Mundo: L’Encyclopédie gratuite en ligne. http://www.cosmovisions.com/Turgot04.htm.

Veblen, Thorstein. 1934. The Theory of the Leisure Class; an Economic Study of Institutions. New York: The Modern library. http://archive.org/details/theoryofleisurec00vebl.

—. 1961. “The Socialist Economics of Karl Marx II.” In The Place of Science in Modern Civilization, by Thorstein Veblen, 431-56. New York: Russell \& Russell.

Vickrey, William. 1992. "Chock-Full Employment without Increased Inflation: A Proposal for Marketable Markup Warrants.” American Economic Review 82 (2): 341-45.

Wasem, Ruth Ellen. 2013. Tackling Unemployment: The Legislative Dynamics of the Unemployment Act of 1946. Kalamazoo, Michigan: W E Upjohn Inst for.

Wisman, Jon D. 2010. “The Moral Imperative and Social Rationality of Government-Guaranteed Employment and Reskilling.” Review of Social Economy 68 (1): 35-67. doi:10.1080/00346760902968405.

—. 2013a. "The Growth Trap, Ecological Devastation, and the Promise of Guaranteed Employment.” Challenge 56 (2): 53-78.

- 2013b. "Why Marx Still Matters.” International Journal of Pluralism and Economics Education 4 (3): 229-42.

—. 2013c. “Government Is Whose Problem?” Journal of Economic Issues 47 (4): 911-38. doi:10.2753/JEI0021-3624470406.

Wisman, Jon D., and Aaron Pacitti. 2014. “'Ending the Unemployment Crisis with Guaranteed Employment and Retraining,' Journal of Economic Issues, 48 (3), September 2014: 679705.” Journal of Economic Issues 48 (3): 679-705.

- 2017. "Guaranteed Employment and Universal Child Care for A New Social Contract." Working Paper 2017- 05: American University Working Paper Series; Forthcoming in Theory and Action, January 2018.

Wisman, Jon D., and Nicholas Reksten. 2013. "Rising Job Complexity and the Need for Government Guaranteed Work and Training.” In The Job Guarantee: Toward True Full Employment, edited by Matthew Forstater and Michael Murray. New York: Palgrave Macmillan.

Wisman, Jon D., and James F. Smith. 2011. "Legitimating Inequality: Fooling Most of the People All of the Time.” American Journal of Economics and Sociology 70 (4): 9741013.

Wray, L. Randall. 1998a. “Government as Employer of Last Resort: Full Employment Without Inflation.” Macroeconomics 9802006. EconWPA. http://ideas.repec.org/p/wpa/wuwpma/9802006.html.

_ 1998b. “Zero Unemployment and Stable Prices.” Journal of Economic Issues 32 (2): 535-45. . 1999. "Public Service Employment-Assured Jobs Program: Further Considerations." Journal of Economic Issues, June. http://www.highbeam.com/doc/1G1-55007575.html. . 2006. Understanding Modern Money: The Key to Full Employment and Price Stability. Cheltenham, UK ; Northampton, MA: Edward Elgar Publishing.

— 2007. "The Employer of Last Resort Programme: Could It Work for Developing Countries?” International Labour Office, Economic and Labour Market Papers, no. 2007-05. 